\title{
Juottomäärän vaikutus vasikoiden tuotantotuloksiin ja tuotannon talouteen kolmivaihekasvatuksessa.
}

\author{
Arto Huuskonen ${ }^{1)}$, Pekka Pihamaa ${ }^{2)}$ ja Hannele Khalili ${ }^{3)}$ \\ ${ }^{1)}$ MTT, Pohjois-Pohjanmaan tutkimusasema, 92400 Ruukki, arto.huuskonen@mtt.fi \\ ${ }^{2)}$ MTT, Taloustutkimus, Luutnantintie 13,00410 Helsinki, pekka.pihamaa@mmm.fi \\ ${ }^{3)}$ MTT, Eläinravitsemus, 31600 Jokioinen, hannele.khalili@mtt.fi
}

\section{Tiivistelmä}

Tutkimuksessa verrattiin vapaata ja rajoitettua juottoa ja niiden vaikutusta vasikoiden kasvuun, rehujen syöntiin ja tuotannon talouteen. Tutkimus sisälsi kaksi vasikoiden juottokoetta (yhteensä 60 vasikkaa) MTT:n Pohjois-Pohjanmaan tutkimusasemalla vuosina 2002 - 2004. Kokeessa oli kolme eri juottotasoa: 6 litraa päivässä, 8 litraa päivässä ja vapaa juotto. Kaksi rajoitetun juoton tasoa kuitenkin yhdistettiin tuloksia laskettaessa, jotta vapaata ja rajoitettua juottoa voitaisiin paremmin vertailla.

Sekä vapaalla että rajoitetulla juotolla juottomäärä kohosi asteittain kokeen kolmen ensimmäisen viikon aikana. Kolmannesta juottoviikosta eteenpäin päivittäinen keskimääräinen juomamäärä vapaalla juotolla oli 9-10 litraa päivässä. Rajoitetuilla juotoilla keskimääräinen juomamäärä oli kolmannesta juottoviikosta eteenpäin 6-7 litraa eläintä kohti päivässä, joka vastasi vasikoille rajoitetussa juotossa tarjottua päivittäistä annosta. Rajoitetusti juotetut eläimet söivät juottokauden (vasikoiden ikä 2vk - 2kk) aikana merkitsevästi enemmän väkirehua $(\mathrm{p}<0.05)$ ja säilörehua $(\mathrm{p}<0.001)$ kuin vapaasti juotetut vasikat.

Kahden kuukauden ikään saakka vapaasti juotetut vasikat kasvoivat nopeammin kuin rajoitetusti juotetut $(\mathrm{p}<0.05)$. Ruokintaryhmien välinen ero elopainon kehityksessä kuitenkin tasoittui vieroitusajanjaksona eläinten 8-10 viikon iässä. Alkukasvatuskauden ruokinnalla ei tässä kokeessa ollut vaikutusta koko kasvatuskauden keskimääräisiin kasvulukuihin ja teurastuloksiin.

Runsas juottoruokinta mahdollistaa rehun kuiva-aineen korkean sulavuuden, muuntokelpoisen energian lisääntyneen saannin sekä rajoitettua juottoa nopeamman painon kehityksen juottokaudella. Vasikoiden terveyden tilaan ei vapaalla ja rajoitetulla juotolla näyttänyt olevan vaikutusta. Tutkimuksen tulokset kuitenkin osoittivat, että runsaan juoton aiheuttama kasvun nopeutuminen vasikkakaudella ei vaikuta myönteisesti eläinten kasvuun koko kasvatuskautta tarkasteltaessa. Taloudellisesti järkevin juottomäärä vasikkakaudella lienee 6 - 8 litraa vasikkaa kohti päivässä. Tätä alhaisemmalla juomamäärällä ruokitut vasikat eivät välttämättä pysty kompensoimaan alkuvaiheen heikompaa kasvutulostaan kasvatuskauden aikana.

Vapaata ja rajoitettu juottoa vertailtiin laskemalla molemmille vaihtoehdoille katetuotto. Katetuottoa laskettaessa otettiin huomioon, että rajoitetun juoton juottoautomaatin hankintakustannukset ovat yleensä huomattavasti korkeammat kuin vapaan juoton järjestämiseen tarvittavan laitteiston hankintakustannukset. Katetuoton, jota laskettaessa oli eri juottolaitteistojen kustannukset otettu huomioon, perusteella rajoitettu juotto oli taloudellisesti vapaata juottoa parempi vaihtoehto. Tosin ero rajoitetun ja vapaan juoton välillä oli melko pieni. Eron taustalla on juottorehun muita rehuja korkeampi hinta. Vasikoiden vapaa juotto on kuitenkin todennäköisesti taloudellisesti perusteltua tapauksissa, joissa vasikoille voidaan juottaa elintarviketeollisuuden sivutuotteena syntyviä maitohuuhteita.

Asiasanat: naudanlihantuotanto, vasikat, tuotannon talous, ruokinta, juomarehut 


\section{Johdanto}

Vasikka kykenee 8-10 ensimmäisen elinviikkonsa aikana hyödyntämään perinnöllisen kasvupotentiaalinsa parhaiten maidolla tai juottorehulla. Perinteisesti pikkuvasikat on Suomessa kasvatettu yksittäiskarsinoissa, jolloin vasikan juoman maitomäärän ja terveydentilan seuranta on ollut helppoa. Nykyään lihantuotantoon menevät vasikat siirretään yleisesti maidontuotantotilalta 7 - 20 päivän ikäisinä naudanlihantuotantotilalle välikasvattamoon. Tällöin ryhmäkoko saattaa olla jopa 50 vasikkaa, ja juottotapana käytetään paljon vapaajuottoa. Suurissa ryhmissä vasikoiden juomat maitomäärät vaihtelevat suurestikin. Ryhmäkasvatuksessakin voitaisiin käyttää rajoitettua juottoa, mutta juottoautomaatin hintaa pidetään usein liian korkeana, mikä on rajannut tämän vaihtoehdon monissa tapauksissa pois. Kuitenkin jos juottoa rajoittamalla päästään kilpailukykyisiin kasvuihin vapaan juoton kanssa, juottoautomaatti maksaa itsensä takaisin säästyneen juomarehukustannuksen kautta. Tässä tutkimuksessa verrattiin vapaata ja rajoitettua juottoa ja niiden vaikutusta vasikoiden kasvuun, rehujen syöntiin ja tuotannon talouteen.

Tiloilla, jotka perustavat vasikoiden alkukasvatuksen vapaaseen juottoon, juoma on yleensä hapatettua. Juoman hapattamisen vaikutusta vasikoiden kasvuun on tutkittu useissa ruokintakokeissa. Suurimmassa osassa kokeita hapanta juomaa saaneet vasikat ovat kasvaneet yhtä paljon tai enemmän kuin hapattamatonta juomaa saaneet. Hapanta juomarehua saaneiden vasikoiden parempi kasvu voi johtua vapaasti tarjotun, hapatetun juomarehun suuremmasta juontimäärästä (Nocek ja Braund 1986, Steen 1991) ja ripulien vähentymisestä (Fallon ja Harte 1988). Hinksin ym. (1980) raportin mukaan juoman hapattamisen vaikutukset vasikoiden kasvuun ovat kuitenkin ristiriitaisia. Jaster ym. (1990) eivät myöskään havainneet juoman hapattamisen vaikuttavan vasikoiden kasvuun rajoitetulla juomarehun saannilla. Todennäköisesti juomarehun hapattamisella on mahdollista saada positiivinen vaikutus vasikoiden tuotantotuloksiin ennen kaikkea silloin, kun kasvatusolosuhteissa ja/tai eläinten terveystilanteessa on ongelmia. Tässä raportoitavassa kokeessa ei käytetty hapatettua juomaa, koska kokeessa käytettiin juottoautomaatteja, joilla on mahdollista tehdä pieniä kerta-annoksia sitä mukaa, kun vasikat käyvät juomassa.

\section{Aineisto ja menetelmät}

Tutkimus sisälsi kaksi vasikoiden juottokoetta MTT:n Pohjois-Pohjanmaan tutkimusasemalla. Vasikat kerättiin paikallisilta lypsykarjatiloilta ternivasikoina keskimäärin 15 vuorokauden ikäisinä. Ensimmäinen juottokoe (30 maitorotuista sonnivasikkaa) aloitettiin marraskuussa 2002, ja se päättyi toukokuussa 2003, jolloin koe-eläimet olivat 6 kk:n ikäisiä. Tämän jälkeen koe toistettiin toisella 30 maitorotuisen vasikan vasikkaerällä (kesäkuu-marraskuu 2003). Molemmissa kokeissa vasikat arvottiin välittömästi tutkimusasemalle tulon jälkeen satunnaisesti kuuteen ryhmään, jotka sijoitettiin kolmelle eri ruokinnalle. Näin kutakin kolmea ruokintakäsittelyä edusti molemmissa kokeissa kaksi eläinryhmää.

Kolme koeruokintaa olivat: 1) vapaa juotto, 2) rajoitettu juotto, jossa suurin sallittu juomamäärä oli 6 litraa vuorokaudessa ja 3) rajoitettu juotto, jossa suurin sallittu juomamäärä oli 8 litraa vuorokaudessa. Juomarehuna käytettiin Startti Instant juomajauhetta, ja kaikkien eläinryhmien juotto tapahtui juottoautomaateilla. Kaikilla ruokinnoilla juomarehujauhetta annosteltiin juottoautomaatin kautta $125 \mathrm{~g} /$ litra vettä. Ruokinnalla 1 vasikat saivat juomaa vapaasti juottoautomaatista. Ruokinnoilla 2 ja 3 vasikat saivat rajoitetun juoma-annoksensa juottoautomaateista pieninä kerta-annoksina (1 - 2 litraa nestettä / kerta). Vasikat olivat koesuunnitelman mukaisilla juotoilla 6 viikkoa eli kahden kuukauden ikään saakka. Tällöin aloitettiin juotolta vieroitus siten, että tarjotun juomarehun määrää vähennettiin päivittäin kahden viikon ajan. Vapaalla juotolla juoman määrää vähennettiin 1 litra/vrk ja rajoitetuilla juotoilla 0,5 litraa/vrk.

Vasikat kasvatettiin 5 vasikan ryhmissä lämpimässä navetassa. Vasikkaa kohti oli karsinatilaa 2,1 $\mathrm{m}^{2}$. Karsinoiden kuivitukseen käytettiin turvetta. Vasikoilla oli koko ajan vettä vapaasti tarjolla juomakupeista. Vasikat saivat juottokokeen ajan lisäksi vapaasti väkirehua ja nurmisäilörehua. Väkirehuna käytettiin teollista täysrehua (Raision MullinHerkku 1). Rehujen kemiallinen koostumus on esitetty taulukossa 1. Säilörehun säilönnällinen laatu kokeen aikana oli hyvä, D-arvo keskimäärin 69 ja syönti-indeksi 99. Rehunäytteiden keruu ja analysointi suoritettiin Huuskosen ym. (2005) tutkimuksessa kuvatulla tavalla.

Juottokauden päätyttyä seurattiin koejuottojen jälkivaikutusta 6 kk:n ikään asti. Juoton loputtua eläimet saivat vapaasti nurmisäilörehua ja vettä, väkirehun annostelumäärä oli maksimissaan 3 kg/eläin/pv. Teollista täysrehua annettiin 4,5 kuukauden ikään saakka, jonka jälkeen väkirehuna alettiin käyttää ohran ja rypsin seosta. Kuuden kuukauden iässä eläimet ryhmiteltiin uuteen tuotantokokeeseen. Vasikkakauden koeasetelma otettiin huomioon lohkotekijänä, kun eläimiä ryhmiteltiin uuteen tuotantokokeeseen, joten juoton vaikutusta painon kehitykseen voitiin seurata teurastukseen saakka. 
Tuloksia laskettaessa kahden kokeen tulokset yhdistettiin. Kullakin koekäsittelyllä oli neljä toistoa, jotka muodostuivat viiden vasikan ryhmistä. Koska vasikoiden kuluttama juomarehun määrä ei poikennut merkitsevästi toisistaan kuuden litran ja kahdeksan litran juotoilla, kuuden ja kahdeksan litran juotot yhdistettiin tulosten laskennassa kuvaamaan rajoitettua juottoa, jota vertailtiin vapaaseen juottoon. Koetulosten tilastollinen käsittely tehtiin SAS-ohjelmiston varianssianalyysillä. Testauksen koemalli oli täysin satunnaistettu koe. Koemalli: $\mathrm{y}_{\mathrm{jk}}=\mu+$ ruokinta $_{\mathrm{j}}+\mathrm{koe}_{\mathrm{k}}+(\text { ruokinta*koe })_{\mathrm{jk}}+\mathrm{e}_{\mathrm{jk}}$.

Taulukko 1. Kokeessa käytettyjen rehujen kemiallinen koostumus.

\begin{tabular}{|c|c|c|c|c|}
\hline & Startti-Instant & Säilörehu & Täysrehu & Ohra \\
\hline Kuiva-aine, g/kg & 927 & 235 & 891 & 887 \\
\hline Kuiva-aineessa, g/kg ka & & & & 27 \\
\hline - tuhka & 71 & 70 & 89 & 36 \\
\hline$-\quad$ raakarasva & 170 & 46 & 52 & 134 \\
\hline$-\quad$ raakavalkuainen & 237 & 172 & 209 & 243 \\
\hline - NDF-kuitu & 2,5 & 534 & 265 & \\
\hline
\end{tabular}

\section{Tulokset ja tulosten tarkastelu}

\section{Rehun syönti, ravintoaineiden ja energian saanti}

Vasikoiden syömät keskimääräiset rehumäärät ja energian saanti juottokaudella (eläinten ikä $2 \mathrm{vk}-2 \mathrm{kk}$ ), vieroituksen aikana ( $2-2,5 \mathrm{kk})$ ja seurantakaudella $(2,5 \mathrm{kk}-6 \mathrm{kk})$ on esitetty taulukossa 2.Vaikka kuivaaineen syönti vaihteli juottokauden aikana ruokintaryhmien välillä ruokintaviikoittain, niin keskimääräinen kokonaissyönti oli samalla tasolla ryhmien välillä. Vapaasti juotetut vasikat saivat juottokaudella syömästään kuiva-ainemäärästä enemmän energiaa, koska juomarehun energiasisältö on väkirehua ja säilörehua suurempi. Vieroituksen aikana sekä kuiva-aineen syönti että energian saanti olivat rajoitetusti juotetuilla vasikoilla merkitsevästi suuremmat kuin vapaasti juotetuilla (Taulukko 2). Seurantakauden aikana (2,5 kk - 6 kk) rehun syöntimäärät ja energian saanti eivät eronneet toisistaan ruokintaryhmien välillä.

Taulukko 2. Vasikoiden rehun syönti ja energian saanti.

\begin{tabular}{|c|c|c|c|c|}
\hline & Vapaa juotto & Rajoitettu juotto & $\mathrm{SEE}^{1)}$ & Tilastollinen merkitsevyys ${ }^{2)}$ \\
\hline \multicolumn{5}{|c|}{ Rehujen syönti, kg ka / pv } \\
\hline \multicolumn{5}{|c|}{ Juottokaudella (2 vk - 2 kk) } \\
\hline - $\quad$ juomarehu & 0,96 & 0,70 & - & \\
\hline - $\quad$ väkirehu & 0,05 & 0,16 & 0,063 & $*$ \\
\hline - $\quad$ säilörehu & 0,02 & 0,05 & 0,008 & $* * *$ \\
\hline - $\quad$ yhteensä & 1,03 & 0,90 & 0,133 & \\
\hline$-\quad \mathrm{ME}, \mathrm{MJ} / \mathrm{pv}$ & 16,01 & 13,45 & 2,008 & $*$ \\
\hline \multicolumn{5}{|c|}{ Vieroituksen aikana $(2-2,5$ kk) } \\
\hline - $\quad$ juomarehu & 0,64 & 0,38 & - & \\
\hline - $\quad$ väkirehu & 0,43 & 1,01 & 0,225 & $* *$ \\
\hline - $\quad$ säilörehu & 0,13 & 0,28 & 0,035 & $* * *$ \\
\hline - yhteensä & 1,20 & 1,67 & 0,195 & $* *$ \\
\hline$-\quad \mathrm{ME}, \mathrm{MJ} / \mathrm{pv}$ & 16,90 & 21,46 & 2,270 & $*$ \\
\hline \multicolumn{5}{|c|}{ Seurantakaudella $(2,5$ - 6 kk) } \\
\hline - $\quad$ väkirehu & 2,56 & 2,62 & - & \\
\hline - $\quad$ säilörehu & 1,69 & 1,71 & 0,158 & \\
\hline - $\quad$ yhteensä & 4,25 & 4,33 & 0,211 & \\
\hline - $\quad \mathrm{ME}, \mathrm{MJ} / \mathrm{pV}$ & 48,51 & 49,48 & 2,397 & \\
\hline
\end{tabular}

${ }^{1)} \mathrm{SEE}=$ Estimaatin keskivirhe. ${ }^{2)}$ Tilastollinen merkitsevyys: ${ }^{* * *} \mathrm{P}<0,001,{ }^{* *} \mathrm{P}<0,01,{ }^{*} \mathrm{P}<0,05$.

Juomarehun kulutus oli korkeampi vapaalla kuin rajoitetulla juotolla (Kuva 1). Keskimääräinen päivittäinen juomamäärä oli vapaalla juotollakin alle kahdeksan litraa kahden ensimmäisen juottoviikon aikana. Kolmannesta viikosta eteenpäin päivittäinen keskimääräinen juomamäärä vapaalla juotolla oli 9-10 litraa päivässä. Juomamäärät ovat samaa suuruusluokkaa kuin vastaavissa aiemmin raportoiduissa vasikoiden juottokokeissa vapaalla juotolla (Appleby ym. 2001, Jasper ja Weary 2002). Juomamäärissä oli suuria eläinkohtaisia vaihteluja, ja suurin yksittäinen juoma-annos kokeen aikana oli 18 litraa päivässä. Rajoite- 
tuilla juotoilla vasikoilla keskimääräiset juomamäärät olivat vastaavasti kahden ensimmäisen viikon aikana 5-6 litraa ja kolmannesta juottoviikosta eteenpäin 6-7 litraa eläintä kohti päivässä.

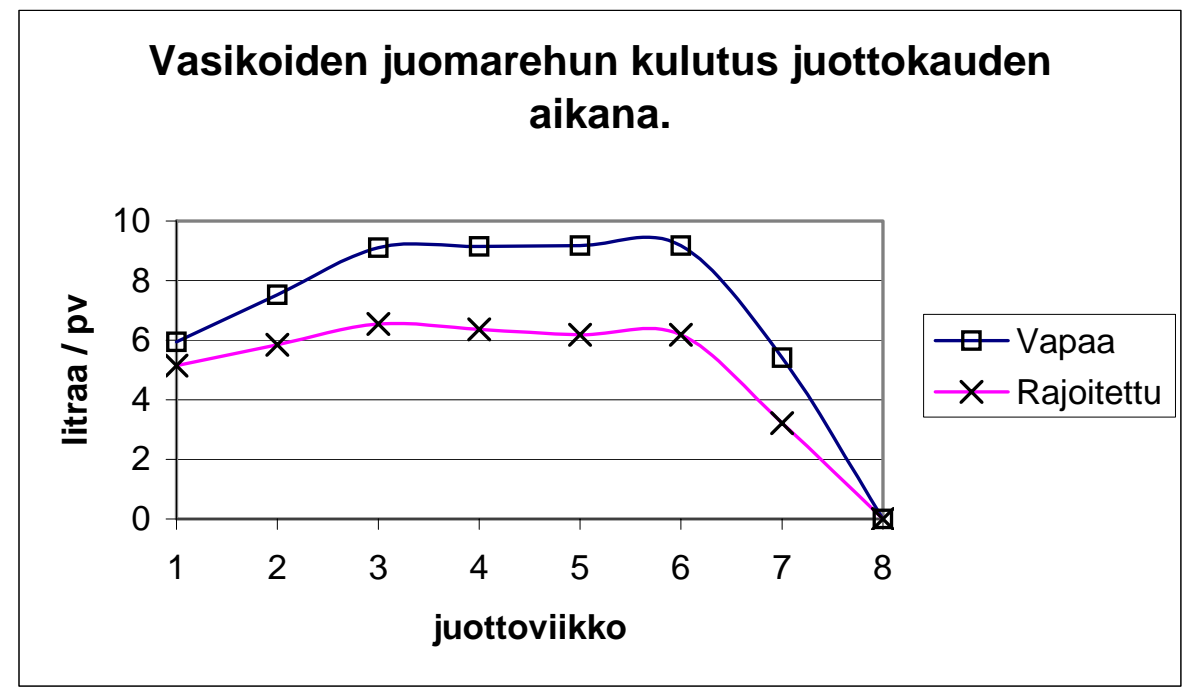

Kuva 1. Vasikoiden juomarehun kulutus juottokauden aikana. Eläinten ikä kokeen alkaessa oli 14 vrk.

Rajoitetusti juotetut eläimet söivät juottokauden aikana merkitsevästi enemmän väkirehua kuin vapaasti juotetut (Taulukko 2). Kun vasikoita alettiin vieroittaa juotolta, rajoitetusti juotettujen vasikoiden kuivan rehun syöntikyky oli parempi, ja ne pystyivät lisäämään väkirehun syöntimäärää selvästi nopeammin kuin vapaasti juotetut (Kuva 2). Väkirehun syönnin kehitys juottokauden aikana noudatti useissa aiemmissa tutkimuksissa (Henderson ja Stewart 1981, Havrevoll 1987, Khalili ym. 2004) saatuja tuloksia. Sama trendi oli nähtävissä nurmisäilörehun syöntimäärissä (Taulukko 2).

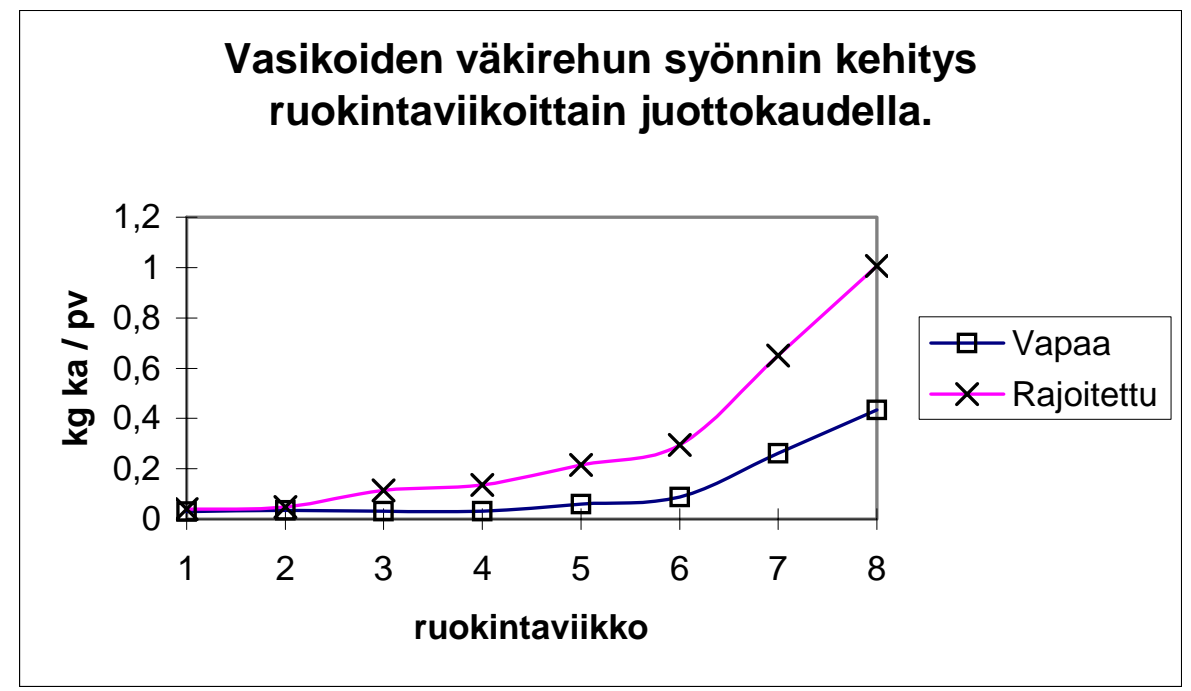

Kuva 2. Vasikoiden väkirehun syönnin kehitys juottokaudella. Eläinten ikä kokeen alkaessa oli 14 vrk.

Kuiva-aineen kokonaissyönnin kehitys on nähtävissä kuvassa 3. Rajoitetusti juotettujen vasikoiden kuivaaineen syönti kehittyi hyvin tasaisesti koko ajanjaksona. Sen sijaan vapaasti juotetuilla eläimillä tapahtui selkeä kuiva-aineen syönnin väheneminen vieroituksen aikaan viikoilla 7-8. Vaikka vieroitus tapahtui juottoautomaatin avulla varovaisesti, vapaasti juotetut vasikat eivät pystyneet siirtymään kuivan rehun käyttäjiksi ilman selvää syönnin notkahdusta. Kesti 1,5 kuukautta vieroituksen jälkeen ennen kuin vapaasti juotettujen eläinten kuivan rehun syöntimäärä oli noussut rajoitetusti juotettujen tasolle (Kuva 3). 


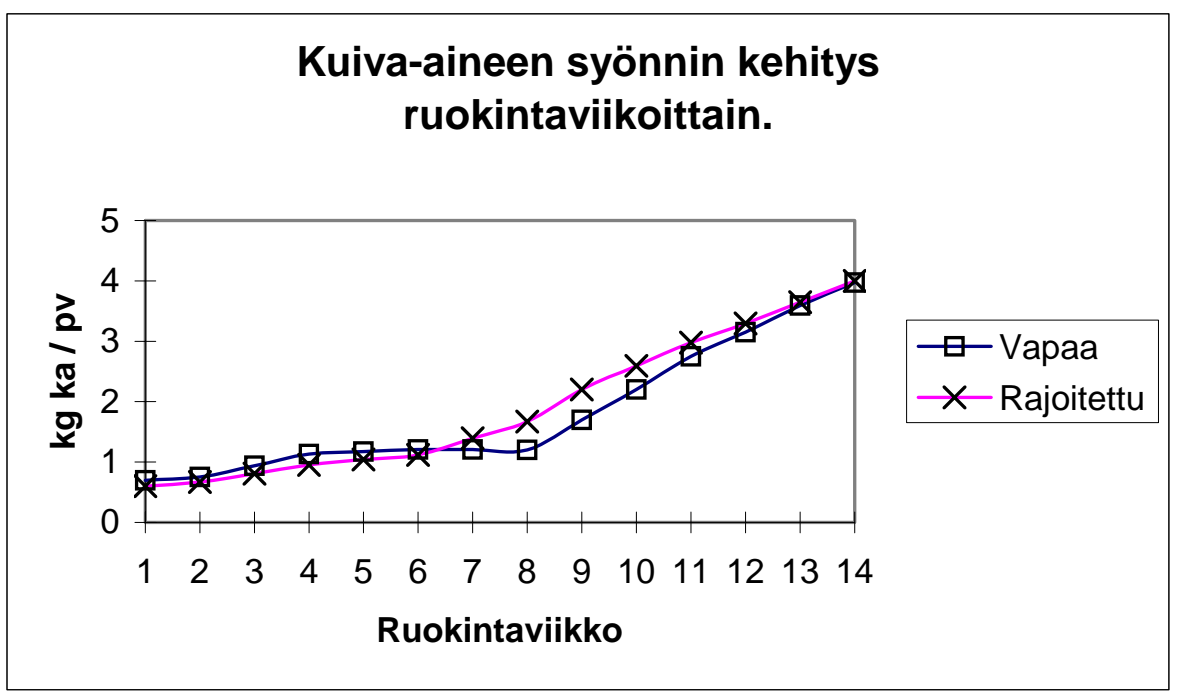

Kuvio 3. Vasikoiden kuiva-aineen syönnin kehitys ruokintaviikoittain. Eläinten ikä kokeen alkaessa oli 14 vrk.

Tutkimuksen tulokset ovat rehujen syönnin osalta yhteneväisiä aiempiin kokeisiin (Havrevoll 1987, Khalili ym. 2004). Hendersonin ja Stewartin (1981) tutkimuksessa väkirehun osuus kuiva-aineensyönnistä vieroituksen aikana oli jopa alle $20 \%$ vapaasti hapanta juomarehua saaneilla vasikoilla, kun samaan aikaan rajoitetusti hapattamatonta juomaa saaneilla vasikoilla väkirehun osuus kuiva-aineensyönnistä oli 66 \%.

Vasikan pötsin kehitys on yhteydessä myös eläimen ikään ja elopainoon, mutta eniten siihen vaikuttaa kuivan rehun syönti (Roy 1980). Pötsin limakalvojen kehitykseen vaikuttaa enemmän väkirehun syönti kuin karkearehu, ja vasikan etumahojen kehitystä voidaan hidastaa runsaalla juottoruokinnalla. Vapaasti juotettujen vasikoiden halu syödä kuivia rehuja on alhainen, koska juomarehu täyttää kaikkien tärkeiden ravintoaineiden saannin vaatimukset. Juoton rajoittaminen lisäsikin tässä tutkimuksessa selvästi vasikoiden väkirehun ja karkearehun syöntiä. Rajoitetulla juottoruokinnalla olleet vasikat söivät kahden ja puolen kuukauden iässä väkirehun kuiva-ainetta noin 1000 grammaa päivässä. Sen sijaan vapaasti juomarehua saaneet vasikat söivät saman ikäisinä vain vajaat 500 grammaa väkirehun kuiva-ainetta päivässä.

\section{Kasvutulokset}

Kahden kuukauden ikään saakka vasikat kasvoivat nopeammin vapaalla juotolla kuin rajoitetuilla juotoilla (Taulukko 3). Tämä johtui lisääntyneen energian saannin lisäksi siitä, että vasikka voi ensimmäisten elinviikkojensa aikana hyödyntää parhaiten juuri juoman mukana saamiaan ravintoaineita (Roy 1980).

Taulukko 3. Vasikoiden kasvutulokset.

\begin{tabular}{|c|c|c|c|c|}
\hline & $\begin{array}{c}\text { Vapaa } \\
\text { juotto }\end{array}$ & $\begin{array}{c}\text { Rajoitettu } \\
\text { juotto }\end{array}$ & SEE $^{\mathbf{1})}$ & $\begin{array}{c}\text { Tilastollinen }^{2)} \\
\text { merkitsevyys }\end{array}$ \\
\hline Elopaino, kg & & & & \\
\hline$-\quad 2$ viikon iässä & 48 & 48 & 3,15 & \\
\hline$-\quad$ vieroituksen alkaessa & 77 & 71 & 4,77 & $*$ \\
\hline$-\quad$ vieroituksen loppuessa & 84 & 83 & 6,44 & \\
\hline$-\quad$ 6 kuukauden iässä & 220 & 218 & 10,30 & \\
\hline$-\quad 18$ kuukauden iässä & 667 & 664 & 41,88 & \\
\hline Päiväkasvu, g/pv & & & & \\
\hline$-\quad 2$ vk 2 kk & 685 & 550 & 103,97 & $*$ \\
\hline$-\quad 2-2,5$ kk (vieroitus) & 521 & 861 & 202,81 & \\
\hline$-\quad 2,5-6$ kk & 1214 & 1212 & 44,44 & \\
\hline$-\quad$ keskim. 2 vk - 6 kk & 1023 & 1017 & 44,44 & \\
\hline$-\quad$ päiväkasvu kahden viikon iästä teurastukseen & 1143 & 1139 & 100,34 & \\
\hline$-\quad$ nettokasvu kahden viikon iästä teurastukseen & 596 & 597 & 5,53 & \\
\hline
\end{tabular}

${ }^{1)} \mathrm{SEE}=$ Estimaatin keskivirhe. ${ }^{2)}$ Tilastollinen merkitsevyys: $* * * \mathrm{P}<0,001, * * \mathrm{P}<0,01, * \mathrm{P}<0,05$. 
Vasikoiden keskimääräiset päiväkasvut jäivät juottokaudella jonkin verran alhaisemmiksi kuin joissakin vastaavissa tutkimuksissa aiemmin. Tämä johtui mahdollisesti siitä, että osalla eläimistä esiintyi juottokauden alkupuolella viruksien aiheuttamaa ripulia sekä hengitystieoireita. Oireet eivät todennäköisesti vaikuttaneet ruokintojen keskinäisiin eroihin, mutta ne vähensivät vasikoiden kasvunopeutta. Hoitoa vaativia oireita oli 20 prosentilla rajoitetusti juotetuista vasikoista ja 30 prosentilla vapaasti juotetuista vasikoista.

Ruokintaryhmien välinen ero elopainon kehityksessä tasoittui vieroitusajanjakson aikana eläinten 810 viikon iässä. Tällä jaksolla rajoitetusti juotetut vasikat kasvoivat keskimäärin 861 g/pv ja vapaasti juotetut vain 521 g/pv. Selitys tähän on löydettävissä paremmasta kuivan rehun syöntikyvystä sitä kautta lisääntyneestä energian saannista, joka oli rajoitetusti juotetuilla vasikoilla selkeästi suurempi juotolta vieroituksen aikaan. Ikävälillä 2,5 - 6 kuukautta vasikoiden kasvuissa ei ollut eroa ruokintaryhmien välillä (Taulukko 3). Eläinten painonkehitystä seurattiin tämän jälkeen aina teurastukseen saakka. Alkukasvatuskauden ruokinnalla ei ollut minkäänlaista vaikutusta loppukasvatuskauden kasvulukuihin tai teurastuloksiin. Juottokaudella tarjottu juomamäärä ei kuitenkaan saa olla liian niukka. Jos vasikan kasvu juottokaudella jää hyvin heikoksi (alle 500 gramman), sitä ei pystytä kompensoimaan loppukasvatuskaudella (Huuskonen ym. 2002). Riittävän energian saannin takaamiseksi rajoitetun juottomäärän tulisi olla 6-8 litraa/vrk.

\section{Juotolta vieroitus}

Vapaasti juotettujen vasikoiden rehun syönti ja energian saanti olivat vieroitusjakson aikana selvästi pienempiä kuin rajoitetulla juotolla olleilla vasikoilla, mikä vaikutti selkeästi kasvuun. Onnistuneen vieroituksen edellytys on kuivan rehun syönnin kehitys mahdollisimman varhaisessa vaiheessa. Ajankohta, jolloin vasikka voidaan vieroittaa menestyksekkäästi, riippuu siitä, koska vasikka syö tarpeeksi kuivaa rehua (800 g - 1 kg väkirehua) ja pystyy käyttämään sitä tehokkaasti hyväkseen. Tulosten perusteella rajoitetusti juotettujen vasikoiden kuivan rehun syöntikyky ja rehun hyväksikäyttö ovat vieroituksen aikaan selkeästi paremmat kuin vapaasti juotetuilla vasikoilla. Vieroituksen toteuttaminen koetaan usein ongelmalliseksi, ja sen toteutukseen on kokeiltu erilaisia ratkaisumalleja. Juottoautomaattia käytettäessä juotolta vieroittaminen onnistuu helposti, mutta vapaalta hapanjuotolta vieroittaminen ryhmäkarsinoissa on huomattavasti vaikeampaa, koska yksittäisen eläimen juomamäärää ei tällöin voi säädellä. Käytännössä vapaalta hapanjuotolta vieroitus tehdään usein lopettamalla juoman tarjoilu yhdellä kertaa (Kemppi 2003).

\section{Vapaajuoton ja rajoitetun juoton taloudellinen vertailu}

Vapaata ja rajoitettua juottoa vertailtiin katetuottolaskennalla. Koska vapaa ja rajoitettu juotto kuitenkin eroavat toisistaan niiden vaatiman työn pääoman määrän osalta, katetuottoa laskettaessa oli välttämätöntä ottaa huomioon nämäkin kustannukset. Rajoitettu ruokinta on mahdollista järjestää sekä manuaalisesti että automatisoituna koneellisesti. Manuaalinen rajoitettu ruokinta ei tosin ole kovin realistinen nykyisissä suurissa välikasvattamoissa, koska työmäärä muodostuisi liian suureksi.

Vapaajuotossa eläinkohtaisen juottolaitteistosta syntyvän kustannuksen määrittely on vaikeaa, koska hankintakustannus ei paljoakaan riipu juotettavien vasikoiden määrästä. Juottolaitteisto perustuu myös usein mahdollisimman edullisiin ratkaisuihin, joita ei yleensä ole julkisesti myytävänä. Esimerkiksi juomarehu sekoitetaan ja säilytetään usein vanhoissa tilatankeissa. Vapaajuoton kiinteitä kustannuksia arvioitiin esimerkkilaskelmalla. Vapaajuottolaitteiston oletettiin maksavan 500 euroa ja kestävän 10 vuotta. Vuosittain laitteistoa käyttää 200 vasikkaa. Kustannukseksi vasikkaa kohti muodostuu tällöin noin 31 senttiä.

Laskelmissa rajoitetun juoton juottoautomaattilaitteiston hankintahintana käytettiin 7100 euroa. Asennuskustannukset arvioitiin 300 euroksi. Juottoautomaatti sisälsi 40 tunnistuspantaa, kaksi juottopaikkaa ja juomarehun sekoituslaitteiston. Laitteiston kestoikänä käytettiin kymmentä vuotta. Laitteiston oletettiin pystyvän hoitamaan yhteensä 40 vasikan ruokinnan. Rajoitetun juoton vaatima työmäärä voitiin olettaa yhtä suureksi kuin vapaa juotossa, kun rajoitettu juotto järjestettiin juottoautomaatin avulla. Laskelmassa oletettiin, että vasikoita juotetaan kaksi kuukautta, jonka jälkeen on kaksi viikkoa taukoa. Näin juottoautomaattia käyttäisi vuodessa viisi erää vasikoita. Laitteiston teoreettinen kapasiteetti on 40 vasikkaa, mutta laskelmissa oletettiin, että keskimäärin laitteiston käyttöasteeksi 90 \% eli 36 vasikkaa. Vuodessa laitteistoa käyttäisi 180 vasikkaa. Vasikkaa kohti rajoitetun juoton laitteistosta muodostui noin 5,14 euron kustannus.

Rajoitettu juotto oli vapaata juottoa edullisempi vaihtoehto, vaikka juottoautomaatin kiinteät kustannukset otettiin mukaan tarkasteluun (Taulukko 4). Laskelmissa käytettyjen oletusten perusteella juoton 
rajoittamiselle näyttäisi olevan perusteita. Jos esimerkiksi juottoautomaatin käyttöaste on pienempi kuin laskelmassa käytetty, ero vapaan ja rajoitetun juoton välillä kuitenkin pienenee.

Taulukko 4. Eri juottoryhmien ylijäämä (euroa eläintä kohti), kun kiinteät kustannukset on otettu huomioon.

\begin{tabular}{|l|r|r|r|r|}
\hline & $\begin{array}{c}\text { Vapaa } \\
\text { juotto }\end{array}$ & $\begin{array}{c}\text { Rajoitettu } \\
\text { juotto }\end{array}$ & \multicolumn{1}{|c|}{ SEE $^{1)}$} & $\begin{array}{c}\text { Tilastollinen } \\
\text { merkitsevyys }\end{array}$ \\
\hline Kallis SR & 86,1 & 91,4 & 34,6 & \\
\hline Halpa SR & 105,2 & 110,4 & 36,5 & \\
\hline
\end{tabular}

${ }^{1)} \mathrm{SEE}=$ Estimaatin keskivirhe. ${ }^{2)}$ Tilastollinen merkitsevyys: *** $\mathrm{P}<0,001, * * \mathrm{P}<0,01, * \mathrm{P}<0,05$.

Kallis SR vaihtoehdossa säilörehu on hinnoiteltu HILA -laskelmien tuotantokustannuksen mukaan.

Halpa SR vaihtoehdossa säilörehu on hinnoiteltu HILA -laskelmien muuttuvien kustannusten perusteella.

\section{Johtopäätökset}

Vapaa juotto mahdollistaa muuntokelpoisen energian lisääntyneen saannin ja rajoitettua juottoa nopeamman painon kehityksen juottokaudella. Juomamäärän lisääminen vaikuttaa yleensä positiivisesti vasikoiden kasvuun juottokaudella. Tarkasteltaessa keskimääräisiä kasvuja eläinten koko eliniän aikana on kuitenkin huomattu, että juottokaudella syntyneet kasvuerot yleensä kompensoituvat kasvatuskauden aikana. Riittävän energian saannin takaamiseksi rajoitetun juottomäärän tulisi olla 6-8 litraa eläintä kohti päivässä. Vapaa juotto lisää juomarehun kulutusta ja vähentää väki- ja karkearehujen syöntiä, jolloin vasikan kehittyminen märehtijäksi hidastuu. Tällöin rehukustannukset kasvavat, koska juomarehut ovat kalliimpia kuin väki- ja karkearehut. Vapaa juotto lienee perusteltua tapauksissa, joissa on käytettävissä elintarviketeollisuuden maitohuuhteita vasikoiden juomana. Juottoautomaatin käytön etuja ovat mm. hallittu juotolta vieroitus, vasikalle sopiva annostelu, mahdollisuus yksilölliseen juomamäärän seurantaan, vasikoiden hyvä ravitsemustaso sekä työnsäästö. Juottoautomaatin kautta juotettu juoma on myös aina oikean lämpöistä ja koostumukseltaan samanlaista. Merkittävin koneiden hankintaa rajoittava tekijä on suuri investointikustannus.

\section{Kirjallisuus}

Appleby, M.C., Weary, D.M. \& Chua, B. 2001. Performance and feeding behaviour of calves on ad libitummilk from artificial teats. Appl. Anim. Beh. Sci. 74 (3): 191-201.

Fallon, R.J. \& Harte, F.J. 1988. Effect of normal or acidified milk replacer offered ad libitum on calf performance. Irish J. Agric. Res. 27: 123-130.

Havrevoll, Ø. 1987. Bøtte- og speneforing av kalvar. Norsk landbruksforsking 1: 189-206.

Henderson, J.J. \& Stewart, R.J. 1981. Methods of weaning calves off acidified milk. Agriculture in Northern Ireland 56: 162-165.

Hinks, C.E., Gilchrist-Shirlaw, D.W., Adams, I.V., Callum, A., Parkinson, H. \& Thomas, D.B. 1980. The effect of acidified milk on calf health and performance. J. Anim. Prod. 34: 460.

Huuskonen, A., Joki-Tokola, E., Valkama, S., Kiljala, J. \& Huttu, S. 2002. Vasikoiden maitojuotto luonnonmukaisessa tuotannossa. Teoksessa: Rinne, M. (toim.). Maataloustieteen päivät 2002: Kotieläintiede. Maaseutukeskusten Liiton julkaisuja 977. Helsinki: Maaseutukeskusten Liitto. s. 160-163.

Huuskonen, A., Khalili, H., Kiljala, J., Joki-Tokola, E. \& Nousiainen, J. 2005. Effects of vegetable fats versus lard in milk replacers on feed intake, digestibility, and growth in Finnish Ayrshire bull calves. J. Dairy Sci. 88: 35753581.

Jasper, J. \& Weary, D.M. 2002. Effects of ad libitum milk intake on dairy calves. J. Dairy Sci. 85: 3054-3058. Jaster, E.H., McCoy, G.C., Tomkins, T. \& Davis, C.L. 1990. Feeding acidified or sweet milk replacer to dairy calves. J. Dairy Sci. 73: 3563-3566.

Kemppi, H. 2003. Ternimaito / täysmaito / juottorehujuoma. Teoksessa: Vasikkaopas. Helsinki: Valio Oy. s. 23-28. Khalili, H., Rinne, M., Aspila, P. \& Aronen, I. 2004. The effect of free or restricted acidified milk feeding of finnish ayrshire bull calves on the subsequent fattening and slaughter performance. Agric. Food Sci. 13: 247-255.

Nocek, J.E. \& Braund, D.G. 1986. Performance, health, and postweaning growth on calves fed cold, acidified milk replacer ad libitum. J. Dairy Sci. 69: 1871-1883.

Roy, J.H.B. 1980. The calf: management and feeding. $4^{\text {th }}$ edition. Lontoo: Butterworths. $442 \mathrm{~s}$.

Steen, R.W.J. 1991. The effect of milk substitute input during calfhood on the lifetime performance of beef cattle. Anim. Prod. 52: 67-74. 